\title{
Area Under the Curve From Dosing to Last Concentration
}

National Cancer Institute

\section{Source}

National Cancer Institute. Area Under the Curve From Dosing to Last Concentration. NCI

Thesaurus. Code C85565.

The area under the curve (AUC) from the time of dosing to the last measurable concentration. 